\title{
Influential Factors of Entering a Nursing Home and Family Intergenerational Relationships in Shanghai
}

\author{
SONG Shan* and OKAMOTO Kohei** \\ *Graduate School of Environmental Studies, Nagoya University; Furo-cho, Chikusa-ku, Nagoya 464-8601, Japan. \\ ** Faculty of Letters, Aichi University; 1-1 Machihata-cho, Toyohashi, Aichi 441-8522, Japan. \\ E-mail: shansong210@gmail.com*, okamotok@vega.aichi-u.ac.jp**
}

Received June 23, 2020; Accepted October 4, 2020

\begin{abstract}
The Shanghai household registered population is highly aged. The elderly occupy a large proportion and continues to increase because of the aging of the generations of one-child families. This study examines the influential factors in the elder care decision-making process of those households with registered elderly people, focusing on changing notions of elder care and changing parent-child relationships. In-depth interviews were conducted with both nursing home residents and community dwelling elderly individuals in downtown Shanghai. Our analysis of the interviews identified three main issues regarding elder care. First, the traditional Filial Piety is changing in response to modern society. Second, family members' inability to provide elder care, the burdens of maintaining an independent household, and nursing home features and conditions are the main factors influencing the decision to enter a nursing home. Third, Filial Piety continues to be expressed through close residential distances between parents and children and a high visit frequency of children's visits to elderly parents.
\end{abstract}

Key words elder care, influential factors, nursing home, family relationships, Shanghai

\section{Introduction}

This paper examines the influential factors related to the care needs of the Chinese elderly, especially in the decision-making process regarding whether or not to enter a nursing home. It focuses on the perspective of family intergenerational relationship between the elderly and their children from two aspects: the proximity of the elderly to their children, and the impact of governmental population policies. Since the One-child Policy implemented in the 1980s, China has experienced a significant change in the number of children per family. While many older elderly have multiple children, the younger elderly generally have only one child. This change has been affecting the elderly's choices for care. The study is set in Shanghai, which is one of the cities with the highest level of aging population in China.

China became an "aging society" in 1999 and has the largest and fastest-growing elderly population in the world (Sun et al. 2015). By the end of 2016, the number of people aged 60 and older ${ }^{1}$ in China was 231 million, $16.7 \%$ of the total population (China National Bureau of Statistics 2017). It is the only country that has more than 200 million elderly people. Within the elderly population, the high-aged ${ }^{2}(\geq 80)$, disabled and semi-disabled, and empty-nesters ${ }^{3}$ (living apart from adult children) sub-groups occupied $10.8 \%, 18.3 \%$, and $51.3 \%$, respectively (Gong 2018). According to the World Population Prospects (United Nations 2019), China’s elderly population will double to 485 million by 2050 , comprising $34.6 \%$ of the total population, and the high-aged elderly will reach 115 million.

A special factor of China's population aging is the Family Planning Policy. It was initially introduced to control excessive growth in the population recoveries after World War II and the Great Chinese Famine (1958-1960). The two rounds of baby boom generation in the 1950s and 1960s increased the total population from less than 500 million to more than 800 million in about two decades and further led to the third baby boom in the 1980s when they got married and became parents (Wakabayashi and Nie 2012; Zeng and Hesketh 2016; Zhang 2017). With the population increase, the Family Planning policy developed from flexible administrative advice of "encouraging birth control" in 1955 to a strict legal regulation of "one couple bear only one child" in 1979. The "One-child Policy" was formally established as a basic national policy in 1982 (Zeng and Hesketh 2016) and implemented for more than 30 years. In 2015, it was altered to the "Two-child Policy" in order to improve the 
population structure and alleviate the pressure of rapid population aging.

The One-child Policy has significantly impacted Chinese society over the past decades and has caused a variety of social issues. First, the fertility rate has continuously dropped, to less than the generational replacement level in the 1990s and to the world's lowest level in 2000. The population pyramid has transformed from an expanding pattern in the 1970s to the current static one. Second, the family scale has reduced and the family structure changed (Liu and Sun 2015). The traditional big family in which multiple generations live together has gradually been replaced by the small nuclear family in which a couple live only with their child. Third, as the generation of the first two baby boomers is also the first generation of the one-child parents, on one hand, as they age over 60 years old in the 2010s to 2020s, the elderly population is predicted to have a substantial increase. According to the forecast made by China State Information Center (2016), the elderly population will hit a peak of 258 million between 2015 and 2021. On the other hand, when the first generation of one-child parents provide care for their previous generation, they have siblings to share the responsibility, but when care is needed from the next generation, they will have only one child to rely on. Thus, China faces a severe challenge to cope with the great pressure on elder care.

Besides, the increase of geographical mobility of the population in the process of urbanization and modernization aggregates the weakening of the family's care function. The notions of elder care show new trends with socio-economic development. As the home-based, community-based and institutional care developped quickly after 2000, the available options for elder care came to be diversified except for the traditional family care. All those above result in the change of elderly people's care needs and the increasing complexity of decision-making for elder care. To provide the elderly with appropriate care, it is necessary to clarify how they choose care and what factors affect their decisions.

This paper aims to understand how the elderly make elder care decisions, and how their relationships with and geographical proximity to their children affect the decision-making. To examine the factors involved in an elderly individual's decision to enter a nursing home, this study conducted in-depth interviews with elderly people living in nursing homes and in communities.

\section{Literature Review}

\section{Cultural notions of elder care}

According to the Confucianism concept of Filial Piety (Xiao), children are obliged to support and provide care for their parents when they age (Zhan et al. 2005; Dai 2019), out of gratitude for parents' contributions to them (Fei 1983). This concept is rooted deeply in ethical principles, and has been passed down generation by generation. Two popular sayings that parents "bring up children for the purpose of being looked after in old age" (Chen 2017a) and children "should not travel afar when your parents are alive" (Zhan et al. 2005) clearly reflect the Chinese family culture. Therefore, aged parents living at home with their children taking care of them is the traditional pattern of elder care in China.

In recent years, younger generations of the elderly tend to be less dependent on adult children and more open to new care patterns other than at-home care. They are less likely to accept much financial support from their children or co-reside with them (Chattopadhyay and March 1999; Zhan et al. 2005). On the contrary, they are likely to subsidize children and spend more time after retirement on assisting adult children with housework and baby care. The younger elderly also attempt to reduce their children's elder care burden. One reason is that many of them have only one child. When that child gets married to a peer from another one-child family and has their own child, the young couple and their four parents and baby have formed the Four-two-one Family Structure (Zhan et al. 2006). As there are no siblings to share the responsibility, taking care of older parents is a stressful task for the young couple. In addition, a faster pace of life, high costof-living, and heavy work pressure (Zhan et al. 2005) in modern society consume much time and energy of the young people, thus reducing their ability for elder care. Moreover, young people's increased geographic mobility interferes with the relationships between children and parents (Wong and Leung 2012). Furthermore, in the past, daughters and daughters-in-law played the main role in elder care provision (Chen 2017a, b). Now that women are more highly educated and career-oriented, the time they can spend on care for elderly parents has decreased (Zhan et al. 2005). In light of these of factors, an increasing number of elderly individuals express their willingness to use community-based and institutional care (Gao et al. 2012; Luo and Zhang 2012).

The original purpose of developing community-based care in China is different from that in Western countries. The similarity is that both of them encourage and support 
elderly people to live independently in their familiar environments as long as possible. However, they differ in their attitudes towards institutional care. In Western countries, from the community care movement in the 1950s to the more recent "active aging", "healthy aging", and "successful aging" movements, the core intention has been to deemphasize dependence on institutions. Whether referring to community-based care, home-based care, or "aging in place" (AIP), they focus on avoiding the isolation and loneliness that many elderly experience in institutions. In China, however, community-based care and institutional care are regarded as a supplement to at-home care. For Chinese people, "home" refers not specifically to a physical location but more to a concept of family togetherness (Chen 2017b).

\section{Care preferences and decision making among the elderly and their families}

The decision that an elder should enter a care facility is often triggered directly by an elder's health crisis or a growing awareness of family members' inability to continue providing care (Lundh et al. 2000). The advice of a professional, such as a physician, that institutional care should be considered is generally regarded as legitimatizing the decision; however, family members may still have feelings of guilt and self-blame. Johnson and Werner (1982) claimed that physical and mental disabilities and the participation of multiple decision-makers can reduce the guilt but that situations such as intergenerational conflict tend to increase feelings of guilt. Paradoxically, family members may feel relieved if they are released from making the difficult decision by themselves. After a decision is made, family members may interact differently with their elderly relative and with the professional caregivers (Lundh et al. 2000).

The pattern of caring for the elderly in China has undergone a transformation in recent years (Gao et al. 2012). Currently, it consists of three main components: traditional at-home care, newly developed communitybased care (or home-based care), and institutional care. $\mathrm{Pu}$ and $\mathrm{Li}$ (2019) indicated that, although at-home care is still the most common form, the willingness to provide at-home care for elderly family members is decreasing with each subsequent generation. At the same time, the acceptance of home-based and institutional care is increasing in younger generations. In Chou's (2010) study, about $20 \%$ of urban elderly people are willing to live in nursing homes. Some elderly people feel abandoned and undignified when thinking about nursing homes, some do not view them positively but also do not feel ashamed, and others are more open to the idea of living in nursing homes and treat them as fulfillment of a modified form of filial piety, preferable to being abandoned at home (Zhan et al. 2005; Chen 2017a).

There are several variables influencing care choice. Factors related to the institution include monthly cost, service quality, facility equipment, environmental conditions, and distance to children's homes (Nagaya and Suzuki 2017). Factors related to the elderly individuals include age, education level, gender, health status, income, and the condition of their residences. In a study by Gao et al. (2012), after age 70, individuals tend to be more open to considering institutional care. An analysis by Tao and Cong (2014) supports this viewpoint, while other studies conclude that an elderly person's health status is the more important factor regarding a preference to live in a nursing home (Luo and Zhang 2012; Yu et al. 2015).

Gao et al. (2012) and Tao and Cong (2014), who collected questionnaire data and conducted quantitative analyses, argued that the elderly in China have come to accept nursing homes. Much of the research in Western countries on studying attitudes towards elder care has also been based on questionnaire surveys and quantitative analysis (Mair et al. 2015; Hajek et al. 2017; Gannod et al. 2018). However, because traditional family norms have a strong influence on elder care in China, it would be difficult to identify through a simple questionnaire survey. In-depth interviews with qualitative analysis is better for the situation in China and enables researchers to explore complicated thoughts behind the interviewee's responses to questions.

\section{Population Aging and Nursing Homes in Shanghai}

\section{Aging and spatial distribution of household registered elderly population}

Shanghai is the metropolitan area located at the delta of the Yangtze River on the east coast of China. With the proportion of persons aged 60 years old and older reaching $10 \%$ in 1979 , Shanghai is the first city to enter the aging society in China, about 20 years earlier than the country as a whole. In addition, Shanghai has the highest level of population aging of China's big cities. In 2016, Shanghai's resident population was 24.2 million. Despite its large relatively young immigrant population, the household registered population of 14.5 million $^{4}$ is highly aged. A total of 4.58 million individuals, over $31.6 \%$, are more than 60 years old. In 2017, the life expec- 
tancy of the household registered population was 83.18 years old (Shanghai Municipal Bureau of Statistics 2017). According to the age distribution of population in 2010 (Figure 1), most elderly people were household registered population, and given the large scale of people aged 50 to 60 years old, the number of the elderly population is predicted to have a substantial increase in the near future.

In terms of the spatial characteristics of the population in 2010, the downtown area of Shanghai (Figure 2) was where the elderly people were most concentrated (Figure 3). About $60 \%$ of the elderly population lived in downtown, with a much bigger density than that in suburbs, which can be seen in Figure 4. The proportion

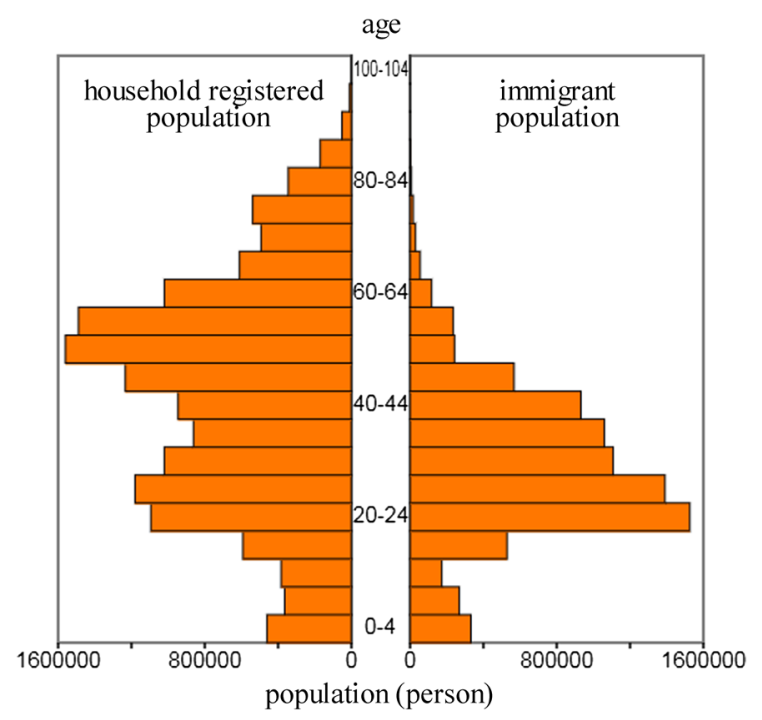

Figure 1. Age distribution of the household registered population and immigrant population in Shanghai, 2010.

Source: China National Bureau of Statistics (2010). of the elderly population showed a high-low-high circle structure from downtown to inner and outer suburbs ${ }^{5}$ (Figure 5). The high proportion in outer suburbs was partly caused by younger generations from the outer suburbs moving to the downtown and inner suburb areas for better job opportunities. Within the elderly population, both the younger and older groups were more distributed in downtown than in suburbs.

\section{Nursing homes in Shanghai}

Shanghai originated the "90-7-3" elder care system in 2005 , which aimed to serve $7 \%$ and $3 \%$ of the elderly with community-based and institutional care, respectively, and support the remaining $90 \%$ to receive the traditional family care at home with assistance from home-based care services. The system consists of various types of facilities and includes services for professional care, meal supply, medical interventions, health promotion, emergency aid, family support, information consultation, and mental health services. Community comprehensive service centers, which train and arrange care workers for to-door services, are located in every subdistrict and town ${ }^{6}$ (Table 1). Meal supply stations, daycare centers, and elder care homes $^{7}$ are integrated into communities. Nursing homes in urban areas and geracomium in rural areas ${ }^{8}$ are the most common care institutions and serve the majority of elderly people. Elderly welfare homes are urban public facilities that mainly serve the "three-no" elderly population, defined as urban elderly individuals with no ability to work, no income and no available caregiver. Geriatric nursing homes are a special type of facility for individuals who suffer from severe illness or at the end-of-life. The

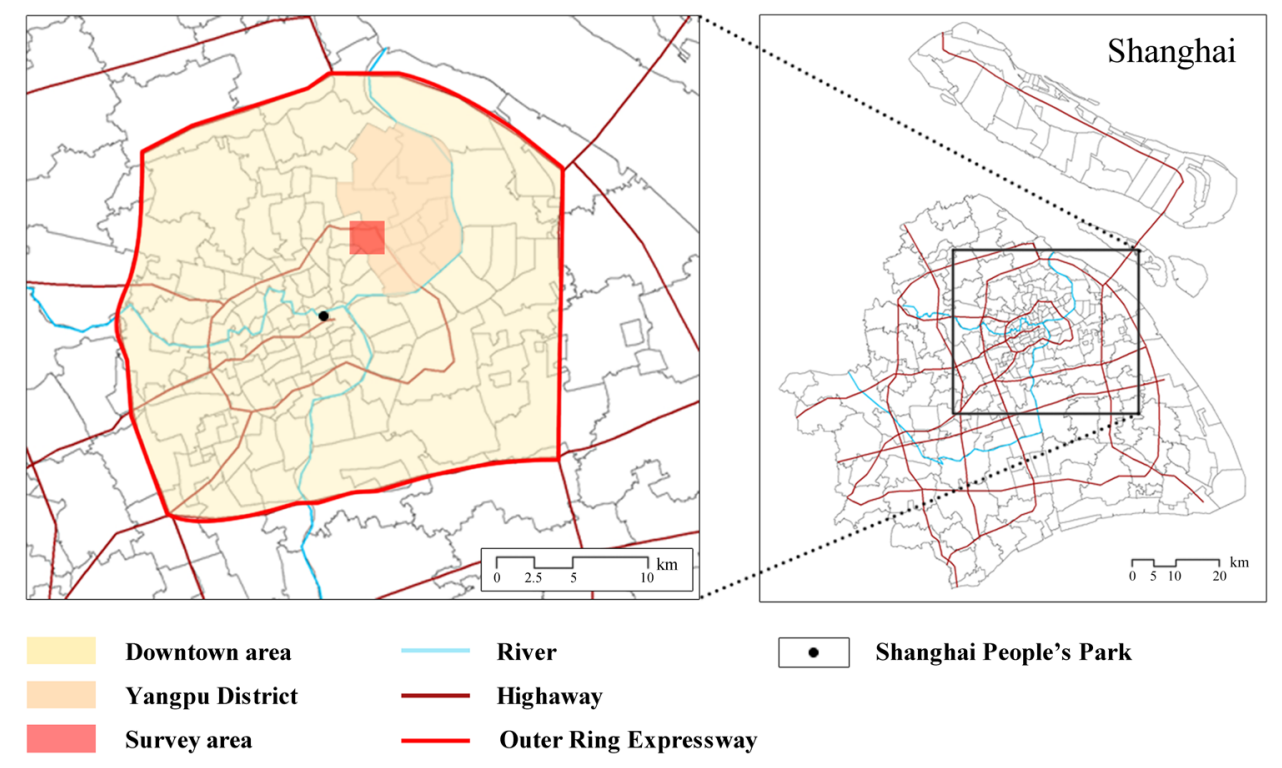

Figure 2. The downtown area of Shanghai and the investigation site. 


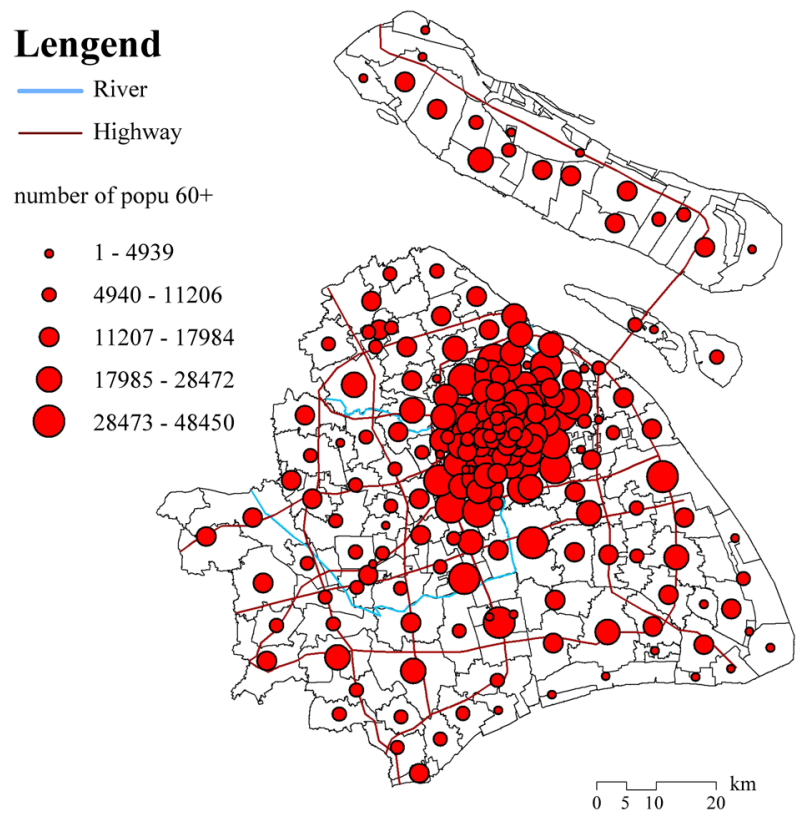

Figure 3. The number of the elderly population (aged $60+)$ in Shanghai.

Source: China National Bureau of Statistics (2010).

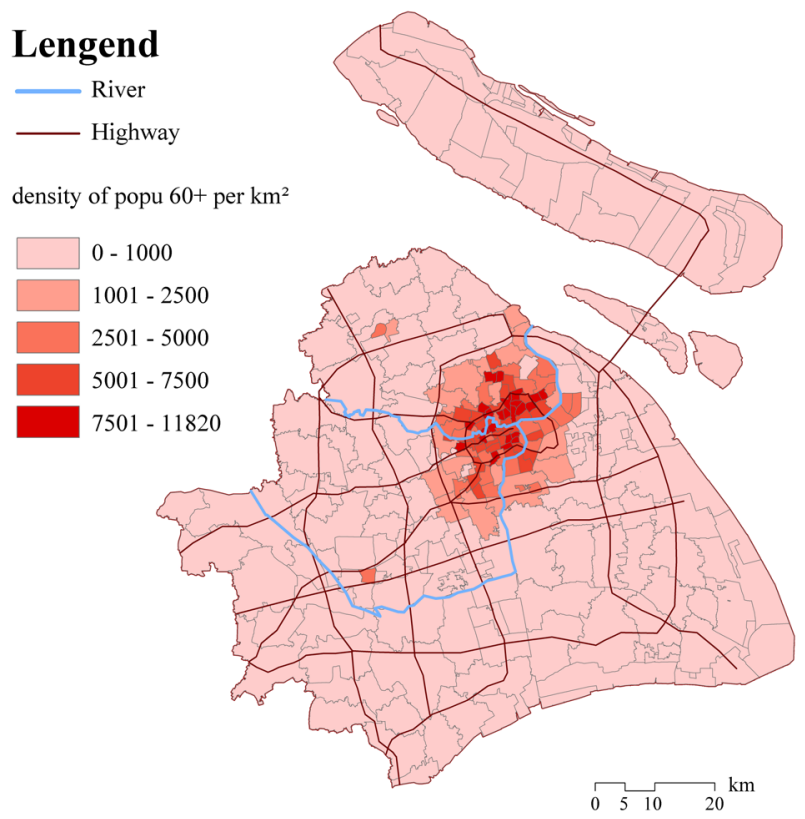

Figure 4. The density of elderly people (aged 60+) in Shanghai.

Source: China National Bureau of Statistics (2010).

newly developed elderly apartments are more expensive and are geared to higher-income individuals.

Nursing homes are the focus of this study. In Shanghai, the services of nursing homes has covered each subdistrict or town. As they are positioned towards the general population, the criteria for entering a nursing home for an elderly are broad: 1) aged more than 60 years old, 2) absence of infectious disease, mental illness or unstable and uncertain diseases, and 3) a willingness to adapt to a collective life with other elderly people ${ }^{9}$. In 2016, there

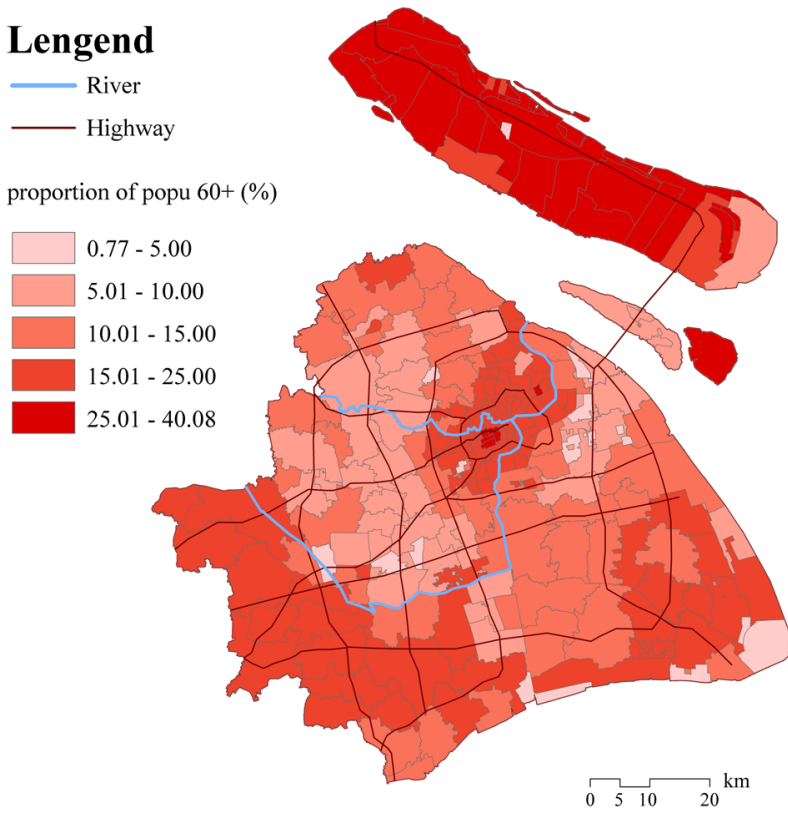

Figure 5. The proportion of elderly people (aged 60+) in Shanghai.

Source: China National Bureau of Statistics (2010).

were 702 nursing homes with 132.8 thousand beds in Shanghai, and half of them located in the downtown area (Figure 6). About $81.13 \%$ of nursing homes are privately operated.

\section{Investigation Site and Data Collection}

\section{Investigation site}

The study aims to collect data of common elderly individuals because they are the majority of the elderly population, and they usually choose the services of general nursing homes. At last, $\mathrm{T}$ area in Yangpu District was chosen as the investigation site (Figure 2).

Among the seven traditional downtown administrative districts in Shanghai ${ }^{10}$, Yangpu District is the biggest with the largest household registered elderly population, 0.35 million in 2016. About $46.8 \%$ of them is distributed in the middle area of Yangpu District. The proportion of elderly population over 60 in Yangpu District was 32.9\%, beyond the average level of Shanghai. In 2016, there were 58 elder care institutions ${ }^{11}$ in Yangpu District, including 53 nursing homes. They totally provided 8,916 beds which served $2.51 \%$ of the elderly population. This service proportion was lower than not only the target $3 \%$ of the "90-7-3" care system but also the average level of $2.9 \%$ of the whole city. For the high concentration and high ageing level of household registered elderly population with the lower level of eldercare service, a place around in Yangpu District is appropriate to be the investigation site of this study.

$\mathrm{T}$ area was chosen for three reasons. First, $\mathrm{T}$ area is 
Table 1. The main types of elder care facilities in Shanghai

\begin{tabular}{|c|c|c|c|c|}
\hline Category & Type & Function & $\begin{array}{l}\text { Property of owner/ } \\
\text { manager-operator }\end{array}$ & Setting \\
\hline \multicolumn{2}{|c|}{$\begin{array}{l}\text { Community comprehensive ser- } \\
\text { vice center for the elderly }\end{array}$} & - manage and provide comprehensive care service for the elderly & $\begin{array}{l}\text { public-public } \\
\text { public-private }\end{array}$ & $\begin{array}{l}\text { cover every sub- } \\
\text { district and town }\end{array}$ \\
\hline $\begin{array}{l}\text { Home-based } \\
\text { care }\end{array}$ & $\begin{array}{l}\text { Elderly service } \\
\text { center }\end{array}$ & - train and arrange care workers for to-door services & public-private & $\begin{array}{l}\text { cover every sub- } \\
\text { district and town }\end{array}$ \\
\hline \multirow[t]{3}{*}{$\begin{array}{l}\text { Community- } \\
\text { based } \\
\text { care }\end{array}$} & $\begin{array}{l}\text { Meal supply } \\
\text { station }\end{array}$ & $\begin{array}{l}\cdot \text { meal supply and delivery } \\
\text { •meals are cooked by catering companies }\end{array}$ & public-private & $\begin{array}{l}\text { cover every sub- } \\
\text { district and town }\end{array}$ \\
\hline & Daycare center & $\begin{array}{l}\text { - provide daytime care } \\
\text { •the elderly commute between homes and daycare centers }\end{array}$ & public-private & $\begin{array}{c}\text { one for every } 15 \text { to } 20 \\
\text { thousand elderly }\end{array}$ \\
\hline & Elder care home & $\begin{array}{l}\text { - residential facility } \\
\text {-function between daycare center and nursing home }\end{array}$ & public-private & $\begin{array}{l}\text { cover every sub- } \\
\text { district and town }\end{array}$ \\
\hline \multirow[t]{4}{*}{$\begin{array}{l}\text { Institutional } \\
\text { care }\end{array}$} & $\begin{array}{l}\text { Nursing home } \\
\text { (urban) } \\
\text { Geracomium } \\
\text { (rural) }\end{array}$ & $\begin{array}{l}\text { - residential facility } \\
\text { - provide comprehensive services for daily life } \\
\text {-free for the "three-no" elderly in urban area and five-guaranteed } \\
\text { elderly in rural area }\end{array}$ & $\begin{array}{l}\text { public-public } \\
\text { public-private } \\
\text { private-private }\end{array}$ & $\begin{array}{l}\text { cover every sub- } \\
\text { district and town }\end{array}$ \\
\hline & $\begin{array}{l}\text { Elder welfare } \\
\text { home (urban) }\end{array}$ & $\begin{array}{l}\text { - residential facility } \\
\text { • mainly for the "three-no" elderly }\end{array}$ & public-public & cover every district \\
\hline & $\begin{array}{l}\text { Geriatric Nursing } \\
\text { Home }\end{array}$ & $\begin{array}{l}\text { - residential facility } \\
\text { • provide life support and rehabilitation service }\end{array}$ & $\begin{array}{l}\text { public-public } \\
\text { public-private }\end{array}$ & \\
\hline & Elder apartment & $\begin{array}{l}\cdot \text { residential house } \\
\text { - provide comprehensive services for daily life } \\
\cdot 3 \text { classes: high, medium, low }\end{array}$ & private-private & \\
\hline
\end{tabular}

Notes: a. The "three-no" elderly indicates the urban elderly who have no ability to work, no income and no legal caregiver (or a legal caregiver who is unable to care for them). Five-guaranteed elderly is the rural elderly who are guaranteed to be provided food, clothes, housing, medical care, and funeral services because they have no ability to work, no income and no legal caregiver.

b. Public facilities usually receive more government subsidies than private ones. "Private" indicates that the facility is owned or operated by individuals, companies or organizations.

Source: Shanghai Municipal Bureau of Statistics (2019)

\section{Lengend}

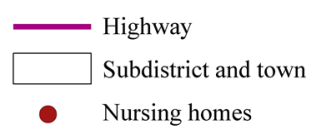

- Nursing homes

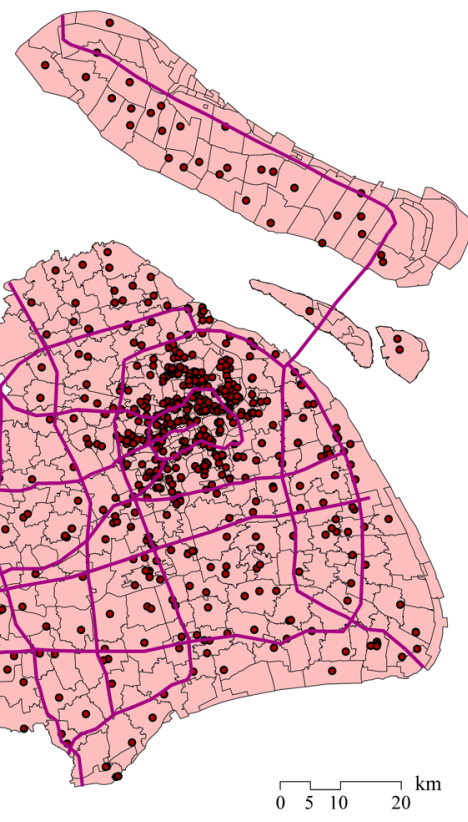

Figure 6. The distribution of nursing homes in Shanghai. Source: Shanghai Civil Affairs Bureau (2013). located in the middle of Yangpu District, between the city center and the Wujiaochang city sub-center, where many elderly people concentrate. It can represent the condition of Shanghai downtown. Second, T area has several big mature residential communities of which many were built in the 1950s to 1990s in Shanghai. As time passed, the residents of those communities gradually aged. Third, there are four private and one public nursing homes around $\mathrm{T}$ area which mainly serve the common elderly population. This study selected S nursing home for its medium size, medium price, and inside environment and two communities not far away from $S$ nursing home to conduct the survey.

\section{S nursing home}

S nursing home was established in 2001 at the peak of the construction of elder care institutions as China became an aging society. After elder care institutions were socialized $^{12}$, the ownership and operation property of $S$ 
Table 2. The introduction of S nursing home

\begin{tabular}{|c|c|c|c|}
\hline & Item & Detail & Charge (unit: CNY) \\
\hline \multirow[t]{16}{*}{ Monthlyfee } & \multicolumn{3}{|l|}{ Care } \\
\hline & Mild level & - be able to take care of oneself & 600 \\
\hline & \multirow[t]{2}{*}{ Moderate level } & -age $>80$ & \multirow[t]{2}{*}{800} \\
\hline & & - be semi-able to take care of oneself & \\
\hline & \multirow[t]{3}{*}{ Severe level } & -age $>90$ & \multirow[t]{3}{*}{$1,000-1,400$} \\
\hline & & •mental disorder & \\
\hline & & - unable to take care of oneself & \\
\hline & \multirow[t]{3}{*}{ Special level } & - serious mental disorder & \multirow{3}{*}{$\begin{array}{l}\text { varies based on } \\
\text { specific situations }\end{array}$} \\
\hline & & - completely reliance on the 24 -hour care service & \\
\hline & & •special service & \\
\hline & \multicolumn{3}{|l|}{ Room } \\
\hline & \multirow[t]{2}{*}{ Double-bed room } & •facing south & 1,880 \\
\hline & & - facing north & 1,500 \\
\hline & \multirow[t]{2}{*}{ Triple-bed room } & •facing south & 1,680 \\
\hline & & -facing north & 1,500 \\
\hline & Meal & •three meals a day & 580 \\
\hline Total monthly fee & & & $2,680-3,860$ \\
\hline \multirow[t]{2}{*}{ One-time fee } & Daily necessities & •bedding sets & 700 \\
\hline & Medical reserve fund & - expense for medical emergencies & 5,000 \\
\hline Total one-time fee & & & 5,700 \\
\hline
\end{tabular}

Source: S nursing home.

nursing home changed from public to private. The current operator is a private company founded in 2009. The construction area is $3,776 \mathrm{~m}^{2}$ and the rated capacity is 100 beds. The bedroom types vary, with the primary types being double-bed and triple-bed rooms. All of the rooms are furnished and equipped with a toilet, bathroom (hot water for 24 hours) and 24-hour calling system. The public space is equipped with a remote surveillance camera and accessibility facilities. The backyard is a small garden with plants and some fitness equipment. In addition to the care workers, two general practitioners, a nurse, and a psychological counselor are employed to provide medical services.

The care services are graded into four primary levels (mild, moderate, severe, special) based on the age, health condition, self-care ability and special needs of the individual. The total monthly fee for care, room and meals varies between CNY 2,680-3,860. The one-time fee for daily necessities and medical reserve fund is CNY 5,700, which is paid at the beginning of the nursing home stay (Table 2).

\section{Communities}

The two communities in this survey are located $1.5 \mathrm{~km}$ and $2 \mathrm{~km}$ away from $\mathrm{S}$ nursing home. One community was intended for the families of the faculty of a university and the other is a residential village of industrial workers. Thus, the residents' education, occupation, and income level are relatively diverse on the individual level. Within a distance of $2 \mathrm{~km}$ from the communities, there are a comprehensive hospital and a sub-district hospital.

\section{Data collection}

The survey was conducted from late September to mid-October 2016 and consisted of in-depth face-toface interviews using a semi-structured questionnaire. The interview topics included demographic information, the daily life in S nursing home or at home, reasons for entering or considering entering a nursing home, factors influencing their care choices, and relationships with adult children. Interviews, which lasted between 30 minutes and 1.5 hours, were recorded by a digital voice recorder, with handwritten back-up notes. The recordings were later transferred into text (more than 258 thousand Chinese characters) for analysis.

The interviewees from $\mathrm{S}$ nursing home were 9 residents (Table 3) and a caregiver aged 55 years old. One of the residents (A7) was unable to answer the questions, and her daughter aged 61 completed the interview. The main points they mentioned about entering a nursing home 
and their previous housing in the dialogues are extracted in Table 4 and Table 5. The community sample consisted of 15 people (Table 6), including one couple (C2). The main points of their comments on entering a nursing home or hiring a housekeeper are listed in Table 7 and Table 8. Interviews took place in home for two interviewees and in public places such as a street park, an elderly activity room, or a community office for the other ones.

\section{Results of the Nursing Home Sample}

\section{Demographic information}

Table 3 shows the attributes of the interviewees in $S$ nursing home. All nine respondents, six females and three males, were more than 75 years old at the time of the survey. Four individuals (A2, A4, A6, A9) entered S nursing home just before turning 75 years old, one (A1) at 78 years old, and four (A3, A5, A7, A8) in their late 80 s. Most of them can afford the nursing home cost of around CNY 3000 per month except A5 and A9. A5 was subsidized by his four children and A9 was supported by the government. Prior to entering the nursing home, five individuals lived in Yangpu District and two in Hongkou
District; areas in close to S nursing home. A2 from Xuhui District and A4 from Huangpu District also lived in the Shanghai downtown area.

Three aspects of health status were assessed in the interview; disease, mobility, and self-care ability. A4 and A7, who were unable to walk by themselves, were classified as having a "weak" level of mobility. A1 and A8 were identified as having "ok" mobility because they needed a walking stick and used elevators instead of stairs. The others, who could walk independently, were considered to have a "good" level of mobility. In general, all of the nursing home residents, especially those who suffered from poor mobility and dementia, were not allowed to leave the nursing home alone for their own safety. They were only permitted to leave if accompanied by family members. However, A9 was permitted to go out freely in the daytime owing to his desire to do so and his good health. A6 was allowed to go out to the supermarket that was within a 15 minute walk.

Self-care ability referred to the ability to do basic personal daily activities such as eating, toileting, and bathing. As A4 and A8 needed the care worker's help for bathing and A5's roommate helped him to get dressed, they were

Table 3. Characteristics of the interviewees in S nursing home

\begin{tabular}{|c|c|c|c|c|c|c|c|c|c|c|c|c|c|c|}
\hline \multirow[b]{2}{*}{ ID } & \multirow[b]{2}{*}{ Gender } & \multirow[b]{2}{*}{ Age } & \multirow{2}{*}{$\begin{array}{c}\text { Years in } \\
\text { nursing } \\
\text { home }\end{array}$} & \multirow{2}{*}{$\begin{array}{c}\text { Current } \\
\text { Income/ } \\
\text { month } \\
\text { (yuan) }\end{array}$} & \multirow[b]{2}{*}{$\begin{array}{c}\text { Former } \\
\text { occupation }\end{array}$} & \multicolumn{3}{|c|}{ Health condition } & \multirow[b]{2}{*}{ Spouse } & \multicolumn{2}{|c|}{$\begin{array}{l}\text { Number of } \\
\text { children }\end{array}$} & \multicolumn{3}{|c|}{ Home before nursing home } \\
\hline & & & & & & Disease $^{a}$ & Mobility & Self care & & Son & Daughter & $\begin{array}{l}\text { Home } \\
\text { address }\end{array}$ & $\begin{array}{c}\text { Distance } \\
\text { from S } \\
\text { nursing } \\
\text { home }\end{array}$ & $\begin{array}{l}\text { Co- } \\
\text { residewith }\end{array}$ \\
\hline A1 & $\mathrm{F}$ & 79 & 1 & $4000+$ & teacher & $5, \underline{9}$ & ok & able & passed away & 2 & 0 & $\begin{array}{l}\text { Yangpu } \\
\text { Dist. }\end{array}$ & $1 \mathrm{~km}$ & child $1^{b}$ \\
\hline A2 & M & 76 & 1.5 & $5000+$ & office worker & $\underline{2}$ & good & able & retired & 2 & 1 & $\begin{array}{l}\text { Xuhui } \\
\text { Dist. }\end{array}$ & $15 \mathrm{~km}$ & $\begin{array}{l}\text { spouse child 1 }{ }^{b} \\
\text { grandson }\end{array}$ \\
\hline A3 & $\mathrm{F}$ & 90 & 3 & $4800+$ & $\begin{array}{l}\text { factory } \\
\text { worker }\end{array}$ & none & good & able & passed away & 3 & 1 & $\begin{array}{l}\text { Hongkou } \\
\text { Dist. }\end{array}$ & $5.5 \mathrm{~km}$ & alone \\
\hline A4 & $\mathrm{F}$ & 85 & 12 & $3000+$ & $\mathrm{N} / \mathrm{a}$ & $1,9, \underline{12}$ & weak & $\begin{array}{l}\text { semi- } \\
\text { able }\end{array}$ & passed away & 2 & 2 & $\begin{array}{l}\text { Huangpu } \\
\text { Dist. }\end{array}$ & $8.5 \mathrm{~km}$ & alone \\
\hline A5 & M & 87 & 9 months & 2800 & engineer & $8,10,11$ & good & $\begin{array}{l}\text { semi- } \\
\text { able }\end{array}$ & passed away & 3 & 1 & $\begin{array}{l}\text { Yangpu } \\
\text { Dist. }\end{array}$ & $3.5 \mathrm{~km}$ & alone \\
\hline A6 & $\mathrm{F}$ & 85 & 11.5 & 3500 & $\begin{array}{l}\text { factory } \\
\text { worker }\end{array}$ & $7, \underline{12}$ & good & able & passed away & 1 & 4 & $\begin{array}{l}\text { Yangpu } \\
\text { Dist. }\end{array}$ & $0.5 \mathrm{~km}$ & alone \\
\hline A7 & $\mathrm{F}$ & 94 & 9 & $\mathrm{~N} / \mathrm{a}$ & N/a & $1, \underline{2}, 3, \underline{9}, 13$ & weak & unable & passed away & 3 & 2 & $\begin{array}{l}\text { Hongkou } \\
\text { Dist. }\end{array}$ & $6.5 \mathrm{~km}$ & child $5^{b}$ \\
\hline A8 & $F$ & 87 & 5 months & 3900 & $\mathrm{~N} / \mathrm{a}$ & $1,3,5, \underline{9}, 11$ & ok & $\begin{array}{l}\text { semi- } \\
\text { able }\end{array}$ & passed away & 2 & 2 & $\begin{array}{l}\text { Yangpu } \\
\text { Dist. }\end{array}$ & $1 \mathrm{~km}$ & child 1 ${ }^{b}$ \\
\hline A9 & M & 78 & 5 & $1000-$ & freelancer & $\underline{2}, 3$ & good & able & unmarried & 0 & 0 & $\begin{array}{l}\text { Yangpu } \\
\text { Dist. }\end{array}$ & $4 \mathrm{~km}$ & alone \\
\hline
\end{tabular}

Notes: a. disease: 1-heart disease; 2-cerebrovascular disease; 3-hypertension; 4-hyperlipoidemia; 5- diabetes/hyperglycemia; 6-gastropathy; 7-calculus; 8-arthritis/Rheumatism; 9-fracture/osteoporosis; 10-parkinson disease; 11-dysaudia/hearing loss; 12-paropsis/vision loss; 13-cognitive disorder; 14-cancer. Numbers with underline means that the disease happened in the past and was nearly healed at the time of this survey. b. See Table 11.

Source: author's interview with the elderly. 
classified as the semi-able level. A7's self-care ability was the worst because she was even unable to eat food by herself. Although some elderly enter the nursing home because they cannot take care of themselves and their children are too busy to help, what they often indicate is not about self-care ability, but that the elderly cannot manage to do the housework such as cooking meals, washing clothes, and cleaning house.

\section{Reasons for entering the nursing home}

There are a variety of reasons for the interviewees to enter a nursing home. Al used to live with her husband and her unmarried older son in a house located $1 \mathrm{~km}$ from S nursing home. In 2010, her husband had a stroke and her sons sent him to the nearby $S$ nursing home, where he lived for 5 years until died. During these 5 years, A1 visited $\mathrm{S}$ nursing home often and became familiar with the care workers and some of the elderly residents. On the day of her husband's funeral, she fell down and broke her hip and consequently had difficulty in going up and down the stairs in her house. Her two sons live on different floors of the house. She decided to enter $\mathrm{S}$ nursing home because she did not want to burden her children. A2 lived with his wife, an unmarried son, and a child of his daughter's, but had poor relationships with the other family members. After a stroke, A2 was sent to S nursing home by his family although he was not willing to go. A3 had lived alone for more than 20 years when all four children left home after marriage. Her health was decent, but after she experienced several minor falls at home, the subdistrict office was concerned about her living alone at home at the age of 87 , and thus sent her to the nursing home. After A4's husband died, she lived with her younger son's daughter for several years to take care of her grandchild. However, after she was diagnosed with heart disease, she was forbidden by her doctor to undertake certain activities which were bad for her heart health, such as washing clothes in cold water. Since it was becoming more difficult to live alone, she chose to go to $\mathrm{S}$ nursing home. A5, who lost his wife in 2015, had Parkinson's disease. He was unable to do daily domestic chores by himself and could not afford to hire a housekeeper, so he decided to enter a nursing home. A6 entered a nursing home 10 years before being interviewed for this study because she had kidney stones and did not want her children to have to care for her. A7 lost her husband early and lived alone for a long time after her children left home. She was hospitalized in 2006 with a hip fracture and was taken to the nursing home by her children after her discharge. A8 lived with her eldest child's family. After being hospitalized for foot surgery, she decided to enter the nursing home. A9 was single and earned very little money. He entered the nursing home after having a stroke.

In addition to residents, a female care worker in $S$ nursing home was interviewed. She had been a care worker for 18 years, 14 years at S nursing home and 4 years at another nursing home nearby. The care worker pointed out that the most common reason that elderly individuals entered a nursing home was that nobody could take care of them at home. This related to factors such as the elderly person's health condition, the relationship with family (especially children), and the availability of housekeepers.

In terms of the elderly's health condition, the care worker emphasized dementia in the above conversation, but with the exception of A7, the interviewees did not suffer from cognitive disorder that would have made it difficult to be interviewed. However, more than half of the elderly had some kind of physical illness before coming to the nursing home that influenced their decision to move there. The physical conditions included poor mobility (A1, A4, A8 in Table 3) and difficulty performing general household chores because of various health conditions (Table 4-a).

In terms of the relationship with family, five of the nine interviewees had lived alone prior to entering the nursing home. Among the remaining four, A2 lived with his wife and child, but the family did not get along well with them. He said "I prefer staying at home, but my family relationship is bad. I and my wife always quarrel with each other. So I am not able to go back home." The care worker said that A2's situation is uncommon.

Many of the interviewees did not want to be a burden to their children, whether or not they were living with them, and this was the reason they decided to enter a nursing home, as shown in Table 4-b. For example, A5 has three sons, and the third son said he would live with A5. However, A5 was concerned that his son would not be able to work if they lived together. He did not want to burden his son in terms of not wanting to be a hindrance to his child's employment. In China, almost all women still have jobs after marriage. Even if elderly people live with their children, they have to be alone while the children are at work. A6 said "If I stayed at home... the children go to work, so I have to wait until they come back to cook dinner." An elderly parent waiting at home can be an emotional burden for working children. A6 also said "They said that taking care of me wouldn't affect their work. They would feel inside as if they intend not to care for me... if let me go to the nursing home." A daughter of A7 said, "we all 
Table 4. Comments on factors related to entering a nursing home

\section{Comments}

a) Health condition

A4: "Because I have a heart disease, the doctor told me that I shouldn't touch cold water anymore nor be too emotional because these things harm my heart health. But I lived alone at that time. If I do the housework, I need to touch cold water. What can I do?"

A5: "I was not able (to do the housework) after I got Parkinson's disease. I could wash clothes and quilt by myself when I was still robust. But my hands lost their power because of that disease."

A6: "Although my disease took a turn for the better and I am managing to do cooking again, it is not possible for me to do more things."

A7 (daughter): "After her bone was fractured, it was not convenient for her to stay at home alone any longer."

\section{b) Family relationship}

A2: "I prefer staying at home, but my relationship with family is bad. My wife always quarrels with me. So I can't go back home."

A4: "I tell my children that I wouldn't live with either of them because, when they go to work in the daytime, I will be the only one at home." My daughters didn't throw me out (to the nursing home). I came here to let them concentrate on their work."

A5: "My third son hasn't reached retirement age. If he stops working to take care of me, he would only get the lowest pension in the future. I said that I can't do that to him. Let me go to the nursing home."

A6: "I said I wanted to go to the nursing home because my children were all busy working..." "There are doctors and care workers (in the nursing home), so the children can be at ease. That's the reason why I came here."

A8: "They are too busy to take care of me. I know they work very hard. So I want to go to the nursing home."

c) Housekeeper availability

A6: "The first housekeeper managed to do many things. She was a local Shanghai resident, so she was good at cooking the Shanghai dishes. But she quit after 1 year because her son got married and needed her back to take care of the grandbaby. The second housekeeper was also Shanghainese and managed the work well, too. Her health was not good because of some disease. So she just did the work for a time, then stopped. The current housekeeper comes from another province. She is not good at the work but that is not the biggest problem because I can teach her how to do it. What I mind the most is she cannot cook the local food. Her taste is different from ours. I cannot adapt to her cooking."

A8: "A family in our situation, you know, hired a housekeeper. After the young couple went to work, only the old father stayed at home... Unexpectedly, the worker stole their belongings and ran away..." "I cannot afford a housekeeper. In addition to paying 4000 yuan for the service, I would need to provide the housekeeper with meals and accommodation. It cost 5000 to 6000 yuan per month in total, which is more than my monthly income. Besides, I also need extra money for my own daily life. So I said I had better go to the nursing home."

Source: author's interview with the elderly.

had our work, so we were not able to take care of her."

To hire a housekeeper is an option for the elderly person which is affected by their financial status and mental health status. The high cost of a housekeeper was mentioned by $\mathrm{A} 8$ as a consideration in their choice to move to a nursing home. If a full-time live-in housekeeper is needed, the total expense, including room and board, may exceed the elderly person's monthly income. If the elderly person only needs an hourly housekeeper several times a week, it may be affordable, but, as mentioned by A6, the quality of service may not meet their standards. A6 mentioned that a housekeeper from a different province is not able to cook the local food. A7's daughter stated that good mental health is a requirement for hiring a housekeeper because the elderly individual needs to oversee the housekeeper's work. Family members often worry about that the housekeeper may not work well, or may abuse the elderly they were if left alone with the housekeeper. A8 also mentioned the worry about that a housekeeper might cheat or steal.

The second reason given by the care worker is that elderly individuals enter the nursing homes to solve the housing problem. One problem is the lack of age-friendly equipment in their previous houses. As Al's comment showed in Table 5, living on the high floors of an apartment without an elevator makes it difficult for the elderly to go up and down as their age increases. Another problem is the size of their previous houses mentioned in the comments of A3 and A4 in Table 5. According to the 2000 Population Census in Shanghai, the average number of bedrooms per house was 2.1 in Shanghai (whole city) and 1.6 in Yangpu District. In addition, the per capita housing area was only $15.84 \mathrm{~m}^{2}$ in Yangpu District, lower than the average of $24 \mathrm{~m}^{2}$ in Shanghai. The small size of housing in downtown Shanghai, especially in oldtype communities where family members live crowded together without an independent space for each person, has led some elderly individuals to enter nursing homes.

In summary, among the reasons mentioned above, getting a disease and losing the ability to care for oneself because of that disease are direct triggers for entering a nursing home. Almost every elderly individual interviewed suffered from certain diseases shortly before they entered the nursing home, and this suddenly or gradu- 
Table 5. Comments about previous housing

\section{Comments}

A1: "When I fractured my leg, I was not able to go up and down stairs, so I came to the nursing home. My younger son lives on the fifth floor and my older son lives on the third floor (with me)."

A3: "My youngest grandson will get married. Because the welfare-oriented public housing distribution system is abolished, he needed to buy the house by himself. So I said I would give my house to him and I would go to the nursing home."

A4: "My older daughter's house has only two rooms, one for my daughter, and the other for my grandson. My grandson has lots of belongings and often invites his friends to his home. I am old with heart disease. I need to sleep which is difficult in the house with my grandson. My younger daughter lives with her mother-in-law. I am not willing to go to her house, either. ... My younger son has no house. He lives in my old house where I used to live before. But it is too small and the toilet is shared by three families. ... I said I want to go to the nursing home."

Source: author's interview with the elderly.

Table 6. The characteristics of the interviewees living in the community

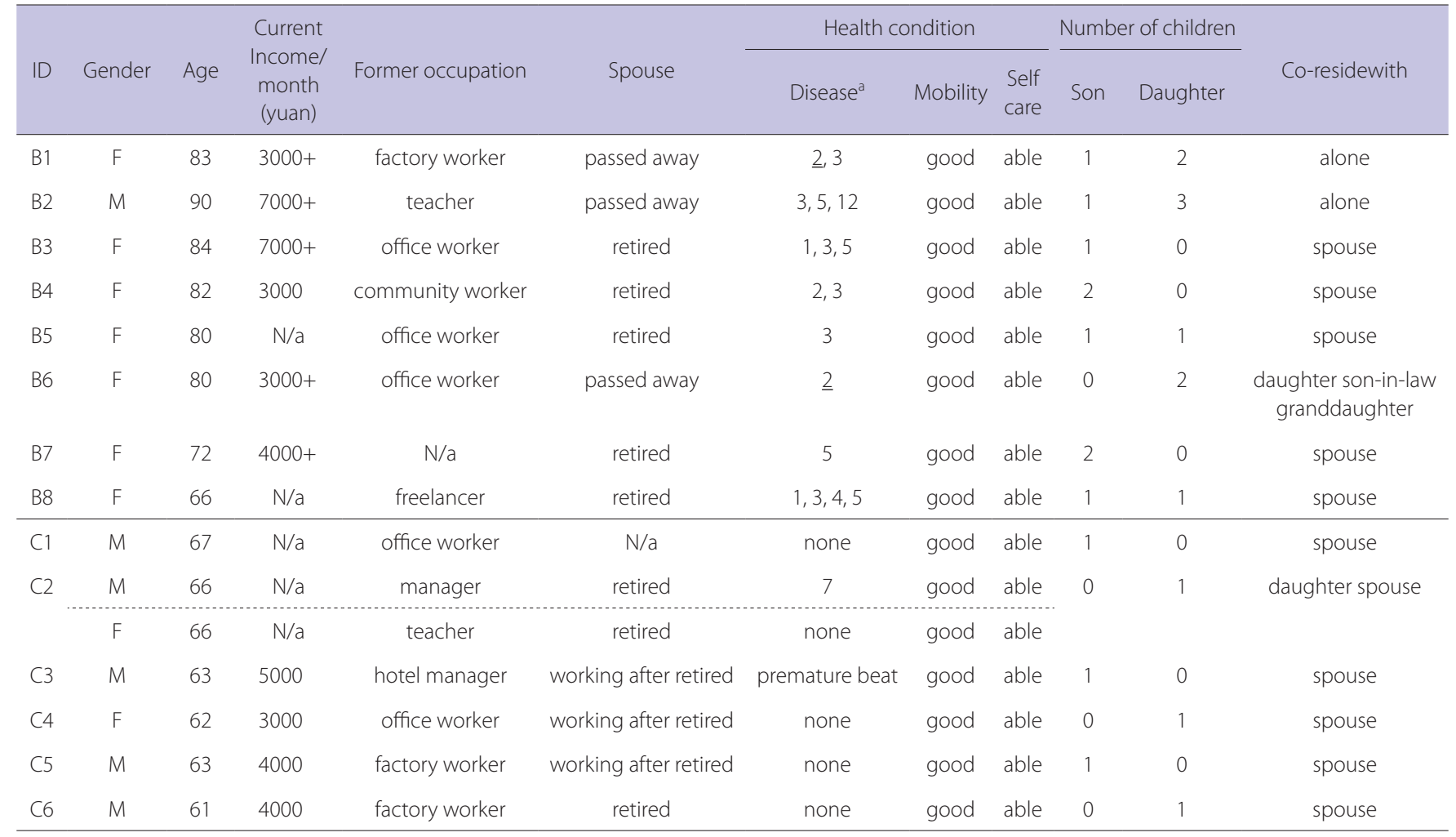

Note: See note a of Table 3.

Source: author's interview with the elderly.

ally weakened their ability to take care of themselves and manage the housework. The diseases include bone fracture or osteoporosis (A1, A7, and A8), stroke (A2 and A9), heart disease (A4), Parkinson's disease (A5) and kidney disease (A6). In A3's case, though she had no disease, she was at high risk of falling down and her family worried about the possibility of bone fracture. Diseases such as hypertension, hyperlipidemia, diabetes, arthritis, osteoporosis, dysuria and vision loss are common among the elderly, but they are chronic. Although together they influence the elderly's health condition, they are not the factors leading directly to a decision to enter a nursing home. Other reasons are the fact that nobody can take care of the elderly, and the residential condition. The for- mer is influenced by the elderly's health condition, family relationship, and housekeeper availability; the latter refers to the structure and size of the elderly family's house.

\section{Results of the Community Sample}

\section{Demographic Information}

Table 6 illustrates the characteristics of the interviewees from the community sample. The elderly interviewees in Table 6 are divided into two groups depending on whether they were affected by the one-child policy on child bearing, those under the age of around 65 at the time of the survey. Group B were unaffected by the one-child policy and have two or more children with 
the exception of B3. However, Group C were affected by the policy and have only one child. B1 and B2 are elderly individuals living alone. B6, a widow, lives in an apartment adjacent to one occupied by her daughter and sonin-law, and C2, a couple, live with their daughter. Of the interviewees in Table 6, all households except B6 and C2 are the so-called "empty-nest households", which consist of elderly individuals only.

\section{Attitude to entering nursing homes}

Sima (2018) surveyed 546 elderly people who are not in nursing homes in downtown Shanghai and analyzed their attitude toward institutional care. Although her study was quantitative and based on a multiple-item questionnaire, the survey was conducted in 2016 and the survey location was similar, so reference to her results is useful.

Regarding the attitudes of elderly people toward nursing home care, Sima (2018) found that $28.2 \%$ of the elderly viewed moving to care facilities as their first choice and $47.8 \%$ of her respondents answered "Yes" to the question regarding their acceptance of living in elder care institutions. Her survey results suggested the elderly individuals have a generally positive attitude toward institutional care, noting that the percentage of those who accept the option of nursing home care was much higher than the approximately 20\% in Chou's (2010) study. The comments in Table 7 , however, show that the attitudes of the elderly towards nursing homes are not so straightforward. The elderly individuals in Group B were generally negative about entering a nursing home, with the exception of B7. For example,

Table 7. Comments about entering a nursing home

\section{Comments}

B1 (F): "When I cannot take care of myself, because my children are busy, they will just send me to the nursing home. That's OK. My mother lived to 98 years old. She was taken care of all by us children."'We are not willing to send (our mother to the nursing home). My mother has her own house. We live together."

B2 (M): Nursing homes may also be considered. There are many things that go into a nursing home decision; acquaintances, culture, human feelings, social habits, willingness to get along with other people.

B3 (F): "They (my neighbors) all want to stay at home. They are not willing to enter nursing homes." We all have a similar opinion that we want to help our children when we have the ability to do so, but we don't want to stay in their places, nor enter the nursing home."

B4 (F): "I haven't considered the nursing home yet. It costs a lot of money. The good nursing homes cost at least 4000 to 5000 yuan every month. The middle level nursing homes cost about 4000 yuan. I have already gathered some information on nursing homes. My sons said they can supplement the money for us to go to the nursing home. We will rent our house out and my sons will provide a subsidy to fill the gap. But my husband is unwilling to go to the nursing home. He is unwilling to stay with other (elderly)."

B5 (F): "I have no plan now. When I cannot take care of myself, I will ask my children to come. I have ever thought of the nursing home. If my spouse passes away one day, what should I do, live with my daughter, live with my son, or go to the nursing home? But it hasn't happened yet, so I will make that decision in the future."

B6 (F): "When I cannot take care of myself, I will have to go to the nursing home. Going there is acceptable but not now. I am not willing to go there actually"

B7 (F): "When I am no longer healthy and need to rely much on them (sons), I shall go (to the nursing home). I definitely have this idea that I will go (to the nursing home). It is convenient."

B8 (F): "Why plan for the care, I will just leave it to decide in the future. I hope there is a nursing home in our community. We can live together. They provide the meals."

C1 (M): "I choose the at-home care. Surely the at-home care. I have my own house, and my salary (retirement pension) is not low. I am sure I can stay at home for care. No matter what I want to eat, or what I want to do... even if I lie in bed, I can pay people to take care of me. But if I go to the nursing home... the current services of the nursing homes are not regulated well." "My mother-in-law used to live in a nursing home for 7 to 8 years. That nursing home is ok. But of course I pay them enough tips. If your tips are not much, things will be different." "The property of nursing homes now is benefitoriented, not morality-oriented. That is the problem."

C2 husband: "I am not considering a nursing home now at all. No need for it. I don't want to think about it. (I hope to) keep healthy, have the ability for daily activities, have a good mental condition, and live a longer life. ... It is hard to say it now. We don't think so much."

C2 wife: "Go to the nursing home when I am older."

C3 (M): "The nursing homes, some nursing homes are good, some other ones are..." Basically, it depends on my health. When my health turns..."

C4 (F): "When I am 70 to 80 years old, my leg may turn bad. I have to stay upstairs every day. No elevator. Nobody to accompany me. It will be the most painful time in my life. Then I shall be sent to the nursing home."

C5 (M): "About my care in the future, (laugh) we will go to the nursing home. We have no choice." "As you surely feel lonely at home, life in the nursing home can be livelier. In case you have an emergency, staying in the nursing home is more convenient (for you to get the help) after all because there are always people there. What can you do if you stay at home?"

C6 (M): "I don't want to enter the nursing home. In my opinion, I don't want to. ... The nursing home is only the choice when you have no other choices." "The nursing homes cost a lot of money. The high-class nursing homes are good but the common ones are unappealing." 
Table 8. Comments about hiring housekeepers

\section{Comments}

B1: "I don't want a housekeeper. It is not a good choice." "(When I lived with my mother,) the community sent us an hourly worker for (housework help such as) doing some laundry. But we then didn't want her help because she was not so engaged in caring for my mom with her heart. We didn't choose to hire a housekeeper."

B3: "I have hired several housekeepers before. But they are not good." "My current housekeeper has a high school education. So she is different from the common ones. It is hard to go along with those housekeeper who come from rural areas." "I pay her a relatively high salary in terms of our income level. I also guarantee her spare time. For instance, if she has some private reasons to ask for a rest, she tells me in advance and I will pay her even though she cannot come. ... She is hard working, not lazy."

B4: "It is not we don't need a housekeeper. We don't have many things (for her) to do. ...I can do the housework by myself, such as cooking. ... (The housekeeper) costs 30 yuan an hour." "It is best to hire a housekeeper at home. But our income is only 3500 yuan per person. After we pay the housekeeper, we have only a little more than 3000 yuan left, by which we need to pay the hospital, to buy food, and to pay the electricity bill. It is not enough." "If we don't need to consider the economic limitation, I also want to hire a housekeeper, not too old, about 50 to 60 years old. To do me favors and take care of us."

B7: "When I am too old to do the things, relying on the children are unrealistic because they are very busy. They cannot... At most it is ok for them to pay the money for hiring a housekeeper. But whether the housekeeper can meet our satisfaction or not is a problem, too." "As the elderly become older, it is harder to make the judgment clear. There are some elderly people whose brains are not so clear." "One problem is you should provide the nanny accommodation. Meal provision is a small problem. Another problem is that none of the children stay with you at home, so if the nanny makes a fool of you, how can you know? It is not safe, we all think so. So it is unworthy."

C1: "No matter what I want to eat, or what I want to do... even if I lie in bed, I can pay people to take care of me." (See C1's comment in Table 7)

C4: "If it is possible, I will hire an hourly worker for cooking, buying things, and washing clothes."

C6: "I don't know what will happen in the future, but currently we absolutely refuse to hire a housekeeper. Because my wife has a rigorous demand for the service quality, which is hard for the housekeeper to accomplish."

Source: author's interview with the elderly.

B1's comment suggested that her generation did not put their parents into nursing homes, so she wished the same for herself, though she thought that her children would be forced to put her in a nursing home if she was no longer able to take care of herself. The elderly in Group C were also less positive about nursing homes, with the exception of C5. In Group C, several male interviewees mentioned the relationship between quality and cost of nursing homes ( $\mathrm{C}$, C3, C6). Receiving high-quality services was expensive. The elderly in Group C experienced market economization in their youth and were likely to be more aware of the existence of higher-end institutional care than older elderly individuals in Group B.

According to Sima (2018), women were more receptive to living in a nursing home than men. This tendency was seen in our study, with males being more negative than females about nursing homes. The opinions of B4 and her husband and C2 couple illustrate the different attitudes between men and women.

One option for those who do not enter a nursing home was to hire a housekeeper. As shown in Table 5, only two out of nine elderly individuals in $S$ nursing home talked about a housekeeper, whereas half of the elderly interviewees who were not in nursing homes commented about a housekeeper, as shown in Table 8. Elderly individuals not in nursing homes were more interested in hiring housekeepers than those in nursing homes. This is because, for them, the only option allowed them to choose to stay at home without being taken care of by their children and without being sent into a nursing home was to hire a housekeeper.

Table 8 includes comments about housekeepers gathered from interviewees not in the nursing home. Although there were some negative opinions about hiring housekeepers like B1 who had a negative image based on her past experiences, most of the comments referred to the quality of the services provided by housekeepers. Though high-quality housekeeper services were available (B3), it was expensive to employ such kind of housekeepers (B4). Their conversations indicated that if they could afford it, they would not enter a nursing home but live at home.

In recent years, community-based care services have been developed to support the elderly to live at home. However, these mainly consist of a meal service and the provision of activities for older people in daycare centers. Most daycare centers do not offer drop-off and pickup services, so the elderly have to walk to get there. Therefore, community-based care services are not an option for elderly individuals who have poor ability to walk or are too old to take care of themselves.

\section{Discussion}

\section{Birthrate change and generation differences}

Confucian Filial Piety has continued to have a significant impact on the parent-child relationship in China. 
Table 9. Comments related to Filial Piety

\section{Comments}

A4: "Many people come to the nursing homes nowadays, but when I came here, other people wondered why I chose the nursing home even though my son and daughters were good to me. My old friends said 'Though your son and daughters had the good conditions (of income and life), you still go to the nursing home?'I answered that the decision to go to the nursing home was for myself. Many people live in nursing homes now. So can I."

A6: "I urged my children not to tell my neighbors (I came to the nursing home). Why not tell them? Their thoughts are old-fashioned." I had no problems except for the kidney stones, but was sent to the nursing home, so I said other people would think you (children) were not filial."

A9: "My daughter-in-law didn't agree. (She said that) if I went to the nursing home, other people would blame her. I said, just let it go. I said there were many people living in nursing homes." "It is not because I had nobody concerned about me that I came to the nursing home. My children said that (the nursing home) was an unpleasant word. I asked, 'Why unpleasant?'I said that there are many people who are coming to nursing homes."

B6: "My children may not allow me to enter the nursing home. They feel ashamed by it."

Source: author's interview with the elderly.

Among younger interviewees, a statement based on this philosophy was found. C6 said "When I was 50 years old, I told my daughter that I would like to live with her when I was older. I expect my child to take care of me because now we help her with baby care and cooking. ...I mean, to live together in the same house." However, A6 in the nursing home said "A person should have a positive thought, rather than the stubborn one that 'I raised the children, thus they should take care of me.' I don't have this kind of thought. I won't give the children agonies to quitting job to keep company with me every day." However, A6 said that when she went into the nursing home, she told her children not to inform the neighbors (Table 9). That was to avoid the children being considered by them to be unfilial. She herself stopped connecting with her neighbors after entering the nursing home. As the comments shown in Table 9, the elderly in the nursing homes were concerned about Filial Piety when they entered the nursing home and the elderly such as B6 who were not in the nursing home were also concerned about Filial Piety. The survey by Sima (2018) showed that the elderly living in downtown Shanghai ranked 'Lighten burden of the family' as the top benefit of living in a nursing home, and 'Public judgment as being abandoned by the family' as the top demerit.

The birthrate decline due to the one-child policy since 1980s, has had a significant effect on the notion of Filial Piety. A7's daughter, who was 61 years old and had only one child said as follows:

We Shanghai local families are almost all one-child families. You know, if you rely on the child, the child will have to take care of four old parents (after getting married). Is it possible? My mother's generation is old. They may feel that going to the nursing home is much too... it is the way for having no other ways. For my generation, I feel I should be conscious and pro-actively consider early which nursing home is good for me, right? Or with my brothers, sisters or friends, we could find a place together and take care of each other. It may be like that.

As she described, the first generation of one-child parents, who were around 60 years old, were still trying to take care of their 80- to 90-year old parents at home. However, when they needed care for themselves, they would have difficulty shown in Table 9 on their only child. Compared with the generation who have multiple siblings with whom to share the caregiving work, the younger generations have to face the challenges by themselves. Jiang (1995) indicated that the dependent parent per child ratio would increase from 0.26 in 1990 to 1.17 in 2030 in urban areas. Because it is not as possible for the younger generation to take care of their parents as previous generations did, they may choose to send parents to nursing homes. Parents are beginning to regard this difficult choice as a new kind of Filial Piety.

It is not only the change in the number of children, but also the change in economic conditions, that affect care decisions. Younger generations tend to have a greater focus on their careers and more participation in the labor force. Consequently, parents do not want to place a burden on their children's time. Moreover, as the younger elderly experienced the hard trade-off between work and caring for family, they are more open-minded to consider nursing homes for themselves. They usually begin to save money for nursing home expenses, and investigate in advance which nursing homes might be most appropriate for them.

The fear of other people's blame and their sense of guilt have significant impacts on decision-making. In the past, people generally thought that only disharmonious families and children who do not honor Filial Piety sent their parents to nursing homes. Thus, for previous generations of elderly individuals, going to a nursing home 
was less acceptable and could even be regarded as shameful. Sending parents to nursing homes is also stressful for the adult children, especially children-in-law. Even now, these ideas exist. But attitudes are also changing owing to the realities that family care for the elderly is not feasible for the one-child elderly generation and therefore nursing homes are becoming more of a viable alternative for many people.

\section{Proximity between elderly individuals and their children}

In Table 3, four of the nine nursing home interviewees lived with their children just before entering the nursing home. However, only two of the fourteen interviewees in Table 6 who were not in nursing homes lived with their children. Their low rate of cohabitation with their adult children may be attributed to the fact that they live with their spouses and do not need the help of their children. From the comments in Table 10-a, it can also be seen that they prefer not to live with their children. As B3 said, they prefer living apart from their children, not only because they do not want to trouble them, but also because they attempt to be independent. The term "generation gap" appears in the C2 comment. Instead of co-residing with their children, elderly people wish strongly to stay close to their children and hope that the nursing homes that they may enter in the future will be located near their children (see Table 10-b).

In fact, the interviewees' children in this study do live near their parents. Table 11 shows the addresses of children and the frequencies of their visits to their parents. For the elderly living in the nursing home (Group A) except A9 who was unmarried, all elderly individuals had at least one child whose address was Yangpu District or Hongkou District. These children resided within $3 \mathrm{~km}$ of $\mathrm{S}$ nursing home. For the elderly who were not in a nursing home (Group B and C), more than $70 \%$ of the parents and children also lived together or in the same neighborhood. Excluding the two cases in which information was not available about the child's address, two of twelve interviewees were living with the child and seven had at least one child living in Yangpu District. There was only one case that a child lived outside the city of Shanghai: B3's child settled in the United States. The statistics from Sima's (2018) survey also show $70 \%$ of the children of elderly people in downtown Shanghai live with or near their parents, and $90 \%$ of them live within the city of Shanghai ${ }^{13}$.

In terms of the frequency of children's visits to parents, once a week is the most common frequency and seems to be an consensus on the level of contact by parents and children. Sometimes, parents suggest their children who live far away or have busy careers to reduce the visit frequency to once a month. And once a month is likely a

Table 10. Comments about the proximity with child by the elderly who are not in the nursing home

\section{Comments}

a) Reasons for not wanting to live with their adult child or children

\footnotetext{
B3 "They (my friends) are not willing to stay in their children's homes. One reason is to avoid troubling their children too much. The other reason is to avoid losing their freedom."

B7: "When I am too old to do things, relying on my children is unrealistic because they are very busy." "If you stay at home and bother them, the more demands you have, the worse you are treated, right?" "But our son has his own things to do, too. He also has his child and family to be responsible for. So why shall we be the burden to him? Don't be too selfish. It's not good to be too selfish."
}

C2 husband: "Don't live with your child. There is generation gap between us. So it is better to keep some space for each other."

C5: "It is impossible to ask the child to care for you. It is not that he is unwilling to take care of you or we are not asking him to take care of us, but that he has no time to do so. It is impossible."

b) Desire to live near their adult child or children

B6: "The nursing home is better so I can live near my (daughter's) home."

B7: "Then, after I enter it (the nursing home), my sons and daughters-in-law can come to see me once a week, and buy something for me to eat. That's enough, it's ok for me, right?" "... If I enter the nursing home, I still want to see them (my children). I will miss them. It is understandable. Maybe they will come (to the nursing home) twice a week, but if it is far away, it is not convenient for them to come frequently. Even coming once a week is inconvenient, right?" "(I will choose) definitely the one (nursing home) near my children. ... No matter how cheap or good it (another nursing home) is I won't go there."

C4: "When I am older, I will sell my current house and move to live near my daughter. I won't live with her in the same house. She comes to see me in her free time and I go to her place when I feel my body is good. This is my idea, my ideal."

C5: "It is best to be close (to my son's house), if possible. If it is too expensive to afford, you have to choose the ones (nursing homes) a little further. The further, the cheaper it may be." "One and a half hours is all right if driving a car."

Source: author's interview with the elderly. 
Table 11. Proximity between elderly individuals and their children

\begin{tabular}{|c|c|c|c|c|c|c|c|c|c|c|c|c|c|c|c|}
\hline \multirow{3}{*}{$\begin{array}{l}\text { ID } \\
\mathrm{A} 1\end{array}$} & \multicolumn{15}{|c|}{ Children's gender (left), address (middle), and frequency of visits to parents (right) } \\
\hline & \multicolumn{3}{|c|}{ Child 1} & \multicolumn{3}{|c|}{ Child 2} & \multicolumn{3}{|c|}{ Child 3} & \multicolumn{3}{|c|}{ Child 4} & \multicolumn{3}{|c|}{ Child 5} \\
\hline & M & $\begin{array}{l}\text { Yangpu } \\
\text { Dist. }\end{array}$ & 2/month & M & $\begin{array}{l}\text { Yangpu } \\
\text { Dist. }\end{array}$ & $1 /$ week & & - & - & & - & - & & - & - \\
\hline A2 & M & $\begin{array}{l}\text { Xuhui } \\
\text { Dist. }\end{array}$ & never & $\mathrm{F}$ & $\begin{array}{l}\text { Hongkou } \\
\text { Dist. }\end{array}$ & $1 /$ week & M & $\begin{array}{l}\text { Songjiang } \\
\text { Dist. }\end{array}$ & never & & - & - & & - & - \\
\hline A3 & $\mathrm{F}$ & $\begin{array}{l}\text { Zhabei } \\
\text { Dist. }\end{array}$ & 2/month & M & Yangpu Dist. & 2-3/week & $\mathrm{F}$ & $\begin{array}{l}\text { Hongkou } \\
\text { Dist. }\end{array}$ & 2-3/week & M & N/a & N/a & & - & - \\
\hline A4 & $\mathrm{F}$ & $\begin{array}{l}\text { Yangpu } \\
\text { Dist. }\end{array}$ & 1-2/week & $\mathrm{F}$ & $\begin{array}{l}\text { Pudong } \\
\text { Dist. }\end{array}$ & $\mathrm{N} / \mathrm{a}$ & M & USA & N/a & M & $\begin{array}{l}\text { Huangpu } \\
\text { Dist. }\end{array}$ & N/a & & - & - \\
\hline A5 & M & $\begin{array}{l}\text { Yangpu } \\
\text { Dist. }\end{array}$ & $1 /$ week & M & $\begin{array}{l}\text { Minhang } \\
\text { Dist. }\end{array}$ & 1/week & M & $\begin{array}{l}\text { Yangpu } \\
\text { Dist. }\end{array}$ & $1 /$ week & $F$ & $\begin{array}{l}\text { Changning } \\
\text { Dist. }\end{array}$ & $\mathrm{N} / \mathrm{a}$ & & - & - \\
\hline A6 & $F$ & $\begin{array}{l}\text { Changshu, } \\
\text { Zhejiang Prov. }\end{array}$ & $1 /$ month & F & $\begin{array}{l}\text { Pudong } \\
\text { Dist. }\end{array}$ & 2/month & $F$ & N/a & $2 /$ month & F & Canada & $\mathrm{N} / \mathrm{a}$ & M & $\begin{array}{l}\text { Yangpu } \\
\text { Dist. }\end{array}$ & 3-4/week \\
\hline A7 & M & $\begin{array}{l}\text { Putuo } \\
\text { Dist. }\end{array}$ & $1 /$ week & M & $\begin{array}{l}\text { Putuo } \\
\text { Dist. }\end{array}$ & $1 /$ week & M & $\begin{array}{l}\text { Hongkou } \\
\text { Dist. }\end{array}$ & $1 /$ week & F & $\begin{array}{l}\text { Putuo } \\
\text { Dist. }\end{array}$ & 1/week & F & $\begin{array}{l}\text { Yangpu } \\
\text { Dist. }\end{array}$ & 1/week \\
\hline A8 & M & $\begin{array}{l}\text { Yangpu } \\
\text { Dist }\end{array}$ & $1 /$ week & M & $\begin{array}{l}\text { Yangpu } \\
\text { Dist. }\end{array}$ & $1 /$ week & $\mathrm{F}$ & $\begin{array}{l}\text { Yangpu } \\
\text { Dist. }\end{array}$ & 1/week & F & $\begin{array}{l}\text { Yangpu } \\
\text { Dist }\end{array}$ & $1 /$ month & - & - & - \\
\hline $\mathrm{A} 9^{\mathrm{a}}$ & & - & & & - & & & - & & & - & & - & - & - \\
\hline B1 & F & $\begin{array}{l}\text { Yangpu } \\
\text { Dist. }\end{array}$ & everyday & $F$ & $\begin{array}{l}\text { Yangpu } \\
\text { Dist. }\end{array}$ & everyday & M & $\begin{array}{l}\text { Yangpu } \\
\text { Dist. }\end{array}$ & seldom & & - & & - & - & - \\
\hline$B 2^{\mathrm{b}}$ & $\mathrm{F}$ & $\mathrm{N} / \mathrm{a}$ & $\mathrm{N} / \mathrm{a}$ & $\mathrm{F}$ & $\mathrm{N} / \mathrm{a}$ & N/a & $\mathrm{F}$ & N/a & N/a & M & $\mathrm{N} / \mathrm{a}$ & $\mathrm{N} / \mathrm{a}$ & - & - & - \\
\hline B3 & M & USA & $\mathrm{N} / \mathrm{a}$ & - & - & - & - & - & - & - & - & - & - & - & - \\
\hline B4 & M & $\begin{array}{l}\text { Yangpu } \\
\text { Dist. }\end{array}$ & $1 /$ week & M & $\begin{array}{l}\text { Baoshan } \\
\text { Dist. }\end{array}$ & $1 /$ month & - & - & - & - & - & - & - & - & - \\
\hline B5 & M & $\begin{array}{l}\text { Yangpu } \\
\text { Dist. }\end{array}$ & $1 /$ week & F & $\begin{array}{l}\text { Putuo } \\
\text { Dist. }\end{array}$ & $1-2 /$ month & - & - & - & - & - & - & - & - & - \\
\hline B6 & F & $\begin{array}{l}\text { Yangpu } \\
\text { Dist. }\end{array}$ & $\mathrm{N} / \mathrm{a}$ & F & same as B6 & everyday & - & - & - & - & - & - & - & - & - \\
\hline B7 & M & $\begin{array}{l}\text { Pudong } \\
\text { Dist. }\end{array}$ & 2/week & M & $\begin{array}{l}\text { Yangpu } \\
\text { Dist. }\end{array}$ & N/a & - & - & - & - & - & - & - & - & - \\
\hline B8 & M & $\begin{array}{l}\text { Yangpu } \\
\text { Dist. }\end{array}$ & $1 /$ week & $\mathrm{F}$ & $\begin{array}{l}\text { Yangpu } \\
\text { Dist. }\end{array}$ & $1 /$ week & - & - & - & - & - & - & - & - & - \\
\hline C1 & M & N/a & $\mathrm{N} / \mathrm{a}$ & & - & & - & - & - & - & - & - & - & - & - \\
\hline$C 2$ & F & same as C2 & everyday & & - & & - & - & - & - & - & - & - & - & - \\
\hline C3 & M & $\begin{array}{l}\text { Baoshan } \\
\text { Dist. }\end{array}$ & 2/week & & - & & - & - & - & - & - & - & - & - & - \\
\hline C4 & F & $\begin{array}{l}\text { Changning } \\
\text { Dist. }\end{array}$ & $1 /$ week & & - & & - & - & - & - & - & - & - & - & - \\
\hline C5 & M & $\begin{array}{l}\text { Yangpu } \\
\text { Dist.. }\end{array}$ & 2-3/week & & - & & - & - & - & - & - & - & - & - & - \\
\hline C6 & $F$ & $\begin{array}{l}\text { Yangpu } \\
\text { Dist.. }\end{array}$ & $\mathrm{N} / \mathrm{a}$ & & - & & - & - & - & - & - & - & - & - & - \\
\hline
\end{tabular}

Notes : a. A9 has no children, but his sister's granddaughter visits him once a month.

b. B2 said his four children would take turns visiting him, but he did not say where the children lived or how often they visited. c. The frequency of visits more than once a week is in bold.

Source: author's interview with the elderly.

minimum level of contact. Only children who have a bad relationship with their parents (A2's children and B1's son) or who live out of Shanghai (A4's son and B3's son), visit less frequently than once a month. The frequency of visits to multi-children parents indicates two ways of cooperation among siblings. One is that siblings visit in turn on different days of the week to guarantee that the parents are visited almost every day (A5 and A7). The other one is that one child, usually the one who lives closest to parents, visits more frequently while the other 
siblings may take a greater share of other aspects of care such as financial subsidies (A6). Some one-child parents help with the care of their grandchildren; thus, they can see their children more often (C3 and C6). Overall, multichildren generations are more likely to have frequent visits than one-child generations.

After the elderly enter nursing homes, children become their main, or even the only, link to the outside world, and this lack of other social connection increases the psychological importance of frequent visits from their children. For the children whose parents are in nursing homes, regular visits to the nursing homes serve as an important way to express to their parents that they are still concerned. Moreover, frequent visits may be an effective way for children to inspect the level of service in the nursing home and the care workers' service quality.

In Table 11, the percentage of children in each group who visited their parents at least once a week, excluding the children whose frequency of visits was unknown, was 68\% (17 of 25 persons) in Group A, 73\% (8 of 11 persons) in Group B and 100\% (4 of 4 persons) in Group C. Overall, $72.5 \%$ of children ( 29 of 40 persons) visited at least once a week. This percentage was significantly higher than the 56\% in Gruijters's (2017) study. Gruijters data were from the National Baseline of the China Health and Retirement Longitudinal Study (CHARLS), which was conducted in the entire country of China in 2011-2012. It was also higher than the figures reported by Gruijters (2017) for the US (55\%) and Japan (56\%), although it was less than the percentage in Italy (86\%); these data were from the International Social Survey Program in 2003. One reason for the high frequency of visits by children in Shanghai is that the Filial Piety norms are strongly maintained in Shanghai ${ }^{14}$. However, a prerequisite for enabling high visit frequency is the close physical proximity between children and the elderly. In $\mathrm{T}$ area of Yangpu District at the time of the survey, those who decided to enter into a nursing home could manage to move into one that was near their children.

\section{Conclusion}

Based on the analysis of interviews with elderly individuals in a nursing home and those living in the community, the study draws the following three conclusions:

First, the notion of Filial Piety has been changing in response to developments in modern society. Nursing homes for elder care, which were previously seen as being synonymous with 'unfilialness' and humiliation, are now viewed as a compromise alternative. They are seen as resolving both children's dilemma between work and care provision, and parents' needs for daily care. Parents and children, especially from the one-child families, tend to reach a tacit agreement that they would rather not abide by a formal Filial Piety such as leaving parents alone at home without sufficient care but instead follow a new one in which they guarantee that their parents are being cared for by others. Second, family members' lack of availability for care provision, the circumstances of home life, and quality of care in nursing homes are the main factors influencing the decision to enter a nursing home. Related factors are elderly people's health status, the relationship between parents and children, and the availability of housekeeping assistance. Third, in Shanghai, parents and children tend to live close to one another and there is a high frequency of children's visits to their parents. The proximity of parents and children indicates an attempt to maintain psychological intimacy. Community-based care and institutional care are a complement to the psychological support that children are able to offer their parents.

This study is unique in that it collected abundant comments about elder care from household registered elderly people, compared groups of elderly individuals living in and out of nursing homes, and revealed the complexity of their decision making and recent changes in factors associated with these decisions. Some limitations exist as well, for example, the study failed to fully address the impact of community-based care facilities on the decision of whether to enter a nursing home. This is due in part to the fact that there were not many available communitybased care facilities and services in 2016. In future work, we expect to make more analysis of the effect of new care options such as community-based care on the elderly's care decision making and increase the number of samples to involve the elderly who use those services. We also expect to make some attempt to quantify the influences of the factors in order to get more exact knowledge, such as how much each of them affects the decision making and the nature of the mutual relationships of the factors.

\section{Acknowledgements}

This work was supported by the China Scholarship Council (No. 201406260217).

\section{Notes}

1. The ages 65 and 60 , respectively, were identified as defining the elderly population by the United Nations in The aging of populations and its economic and social implications published in 1956, and the report of the First World Assembly on Ageing published 
in 1982. Thus, if a country or region's percentage of population aged 60 (or 65) and over surpasses 10\% (or 7\%) of the total population, that country or region is considered an aging society. In China, the Law on Protection of the Rights and Interests of the Elderly defines the elderly as people aged 60 and older, while both the age 60 and 65 are used in population statistic indexes. According to the Green Paper on Population and Labor (2017) published by the Chinese Academy of Social Sciences, the statutory retirement age will be gradually delayed from age 60 for males and age 55 for females in 2018 to age 65 for all people in 2045.

2. In China, elderly people are classified into three groups by age (Wu 1997): the low-aged elderly (60-69 years old), the middleaged elderly ( $70-79$ years old), and the high-aged elderly ( 80 years old and over).

3. The concept of "empty nest" was first put forward by the American scholar Paul C. Glick (1947). Empty-nest elderly individuals indicates those living separately from their adult children.

4. The household registration system (Hukou) is a governmentenforced system that categorizes the population by their place of residence (rural or urban) and eligibility for certain socioeconomic benefits (agricultural or nonagricultural) (Wei and Sheng 2020).

5. According to the Shanghai Master Plan 2017-2035, downtown Shanghai is the area within the line of Shanghai Outer Ring Expressway, which nearly corresponds to a circle with a radius of $15 \mathrm{~km}$ from the People's Park. The circle with a radius of $30 \mathrm{~km}$ demarcates the suburban area as "inner suburbs" and "outer suburbs" (Huang et al. 2008). The administrative divisions of Shanghai in 2016 consist of three levels from higher to lower: 1) direct-controlled municipality on prefecture level; 2) 16 districts on county level; 3) 104 subdistrict, 107 towns, and two townships on township level excluding three special township-level divisions. With the urbanization, many old towns are replaced by new subdistricts. Below the township level, there are residential communities and villages which are the basic unit of administration. https://en.wikipedia.org/wiki/List_of_township-level_divisions_ of_Shanghai (Retrieved on 20 September 2020)

6. The elder care home is a new kind of care facility, which is positioned between daycare centers and nursing homes. It was first introduced in a pilot project in 2014, then normalized in 2015, and popularized throughout Shanghai in 2017. Because there have been few elder care homes established by the time of this study, these were not referred to in this paper. http://www.shweilao.cn/ $\mathrm{cms} / \mathrm{cmsDetail}$ ?uuid $=\mathrm{e} 9 \mathrm{db} 0 \mathrm{c} 75-\mathrm{b} 811-47 \mathrm{bb}-\mathrm{bf} 41-5586 \mathrm{f} 5551 \mathrm{df} 1$ (Retrieved on 12 June 2020)

7. Generally speaking, Shanghai is divided into the downtown area and suburban area. The urban areas mean the Shanghai downtown and the central areas of suburban towns where the town governments are locate and directly administer. The non-central areas in suburbs are the rural areas. The residential elder care facilities in urban areas are usually named as nursing homes, and those in rural areas as geracomium.

8. Procedures and condition of entering a nursing home. http:// www.021shiji.com/about/?10.html (Retrieved on 12 June 2020)

9. The traditional seven downtown administrative districts are Huangpu, Jingan, Changning, Putuo, Xuhui, Hongkou, Yangpu District, except Pudong New District, which was established in 1990.

10. The elder care institutions included 53 nursing homes, two welfare homes, two elderly apartments and an elder care home. The total beds provided by 53 nursing homes were 7,219.

11. In the 1980s, China began welfare socialization with a marketoriented welfare system through market-oriented fundraising and supply of services (Dai 2019). The elder care institutions such as nursing homes quickly developed, and the operation of many public nursing homes changed from public to private.

12. In Sima's (2018) survey, $33.9 \%$ of the elderly lived with children, $38.5 \%$ had children living nearby, and $17.2 \%$ had children living in the same city.

13. In 2016, Shanghai passed its own Law on Protection of the Rights and Interests of the Elderly. Article 14 of this law states that family members should be concerned with the mental needs of the elderly, give them mental comfort, create a harmonious and caring family atmosphere, and must not ignore or neglect them; family members who live separately from the elderly should often visit and greet them; family members should often visit the elderly living in nursing institutions; the nursing institutions can suggest and urge family members who have not visited the elderly for a long time to visit more frequently.

14. The care worker in $S$ nursing home answered the question if elderly individuals need to wait (for a bed) to enter the nursing home. "No, they don't need to. We have available beds. But some available beds are in the north-facing rooms or multi-person rooms, which are less preferred by the residents."

\section{References}

Chattopadhyay, A. and Marsh, R. 1999. Changes in living arrangement and familial support for the elderly in Taiwan: 1963-1991. Journal of Comparative Family Studies 30: 523-537.

Chen, M. 2017a. China's elderly care: From national welfare regime to localized care provision structure. Master's thesis, Utrecht University.

Chen, S. Y. 2017b. Population ageing and social policy: On the Chinese "Jia" and the elder care. Population et Sociétés (1): 63-72. (CE)

China National Bureau of Statistics. 2010. The 6th nationwide population census of the People's Republic of China.

China National Bureau of Statistics 2017. China national economic and social development statistical bulletin 2016. 28 Feb. 2017. http://www.stats.gov.cn/tjsj/zxfb/201702/t20170228_1467424. html (Retrieved 12 June 2020)

China State Information Center 2016. China's population aging trend and its impact. 22 Jan. 2016. http://www.sic.gov.cn/ News/455/5900.htm (Retrieved 12 June 2020)

Chou, R. J. A. 2010. Willingness to live in eldercare institutions among older adults in urban and rural China: A nationwide study. Ageing and Society 30: 583-608.

Dai, W. 2019. V-shaped responsibility of China's social welfare for the elderly: Based on analyzing historical evolution and future sustainability. Sustainability 11: 2385.

Fei, X. T. 1983. The problem of elderly support in the change of family structure: Rediscussing the change of family structure in China. Journal of Peking University: Philosophy and Social Sciences Edition 3: 6-15. (C)

Gannod, G. C., Abbott, K. M., Van Haitsma, K., Martindale, N. and Heppner, A. 2018. A machine learning recommender system to tailor preference assessments to enhance person-centered care among nursing home residents. The Gerontologist 59: 167-176.

Gao, X. L., Yan, B. Q. and Ji, J. 2012. Urban elders' desirable caring patterns and its rationality: A decision tree analysis. Progress in Geography 31: 1274-1281. (CE) 
Glick, P. C. 1947. The family cycle. American Sociological Review 12: $164-174$.

Gong, W. B. eds. 2018. Blue book of social institution: Report on social institutional reform in China No. 6 (2018). Beijing: Social Sciences Academic Press. ISBN: 978-7-5201-2443-0 (C)

Gruijters, R. J. 2017. Intergenerational contact in Chinese families: Structural and cultural explanations. Journal of Marriage and the Family 79: 758-768.

Hajek, A., Lehnert, T., Wegener, A., Riedel-Heller, S. G. and König, H. H. 2017. Factors associated with preferences for long-term care settings in old age: Evidence from a population-based survey in Germany. BMC Health Services Research 17: 156.

Huang, X. M., Wu, X. and Shi, J. Q. 2008. Comparison and enlightenment of rail transit in three metropolitan areas: Tokyo, Shanghai and Zhongjing. Journal of Transportation Engineering and Information 6: 31-36.

Jiang, L. 1995. Changing kinship structure and its implications for old-age support in urban and rural China. Population Studies 49: 127-145.

Johnson, M. A. and Werner, C. 1982. "We had no choice": A study in familial guilt feelings surrounding nursing home care. Journal of Gerontological Nursing 8: 641-654, 654.

Liu, T. and Sun, L. 2015. An apocalyptic vision of ageing in China. Zeitschrift für Gerontologie und Geriatrie 48: 354-364.

Lundh, U., Sandberg, J. and Nolan, M. 2000. 'I don't have any other choice': Spouses' experiences of placing a partner in a care home for older people in Sweden. Journal of Advanced Nursing 32: $1178-1186$.

Luo, N. and Zhang, Y. C. 2012. An empirical study on the factors which influence the will of the aged in the urban by using the Order Probit Model. Journal of Xian University of Finance and Economics 25: 97-102. (CE)

Mair, C. A., Quiñones, A. R. and Pasha, M. A. 2015. Care preferences among middle-aged and older adults with chronic disease in Europe: Individual health care needs and national health care infrastructure. The Gerontologist 56: 687-701.

Nagaya, E. and Suzuki, H. 2017. An analysis on the welfare facilities for the elderly in Dalian city and Xian city. AIJ J. Technol. Des. 23: 283-288. (JE)

$\mathrm{Pu}, \mathrm{H}$. S. and Li, S. Y. 2019. Status and trend of the desirable caring patterns for elderly of different generation in Chengdu City. China Medical Herald 16: 68-71. (CE)

Shanghai Civil Affairs Bureau 2013. Data of Shanghai eldercare facilities. http://app.mzj.sh.gov.cn/sample/Gis.aspx?object $\mathrm{id}=166$ (Retrieved on 12 December 2013)

Shanghai Municipal Bureau of Statistics 2017. Shanghai municipal economic and social development statistical bulletin 2016. 2 Mar. 2017. http://tj.sh.gov.cn/tjgb/20170302/0014-293816. html (Retrieved 12 June 2020)

Shanghai Municipal Bureau of Statistics 2019. Shanghai commu- nity embedded elder service work guidelines. http://www. shanghai.gov.cn/nw12344/20200813/0001-12344_63121.html (Retrieved 26 May 2020)

Sima, L. 2018. Concerns on elderly care institutions among Chinese urban elders and differences between individuals: Evidences from Shanghai. AIJ J. Technol. Des. 24: 1145-1148.

Sun, W., Aodeng, S., Tanimoto, Y., Watanabe, M., Han, J., Wang, B., Yu, L. and Kono, K. 2015. Quality of life (QOL) of the community-dwelling elderly and associated factors: A populationbased study in urban areas of China. Archives of Gerontology and Geriatrics 60: 311-316.

Tao, T. and Cong, C. 2014. An analysis of influencing factors on elder's preference for patterns of old-age support: Some empirical evidence from Beijing Xicheng District. Population \& Economics 3: 15-22. (CE)

United Nations, Department of Economic and Social Affairs, Population Division 2019. World population prospects 2019, highlights. New York: United Nations.

Wakabayashi, K. and Nie, H. ed. 2012. Chuugoku jinkou mondai no nenpu to toukei-1949-2012 nen (Chronology and Statistics of China's Popuration Issues: 1949-2012). Tokyo: OchanomizuShobo. (J)

Wei, H. and Sheng, G. 2020. Rural-Urban integration and household registration system reform. In Comprehensive deepening of reforms in China, ed. L. Peilin, 107-130. Springer: Singapore.

Wong, Y. C. and Leung, J. 2012. Long-term care in China: Issues and prospects. Journal of Gerontological Social Work 55: 570586.

Wu, Z. G. 1997. Population science dictionary. Chengdu: Southwestern University of Finance and Economics Press.

Yu, J., Rosenberg, M. W. and Cheng, Y. 2015. Aging at home and the intent to relocate in Beijing. Progress in Geography 34: 1577-1585. (CE)

Zeng, Y. and Hesketh, T. 2016. The effects of China's universal twochild policy. Lancet 388: 1930-1938.

Zhan, H. J., Liu, G. and Bai, H. G. 2005. Recent development in Chinese elder homes: A reconciliation of traditional culture. Ageing International 30: 167-187.

Zhan, H. J., Liu, G. and Guan, X. 2006. Willingness and availability: Explaining new attitudes toward institutional elder care among Chinese elderly parents and their adult children. Journal of Aging Studies 20: 279-290.

Zhang, J. 2017. The evolution of China's one-child policy and its effects on family outcomes. The Journal of Economic Perspectives 31: 141-160.

(C) written in Chinese

(CE) written in Chinese with English abstract

(J) written in Japanese

(JE) written in Japanese with English abstract 